Letter to the Editor

\title{
Predictors of visual outcome and the role of early vitrectomy in Streptococcal endophthalmitis: response
}

\author{
Emil D Kurniawan MBBS, ${ }^{1}$ John R Rocke MBBS, ${ }^{1}$ Sukhpal S Sandhu MD FRANZCO ${ }^{1,2}$ \\ and Penelope J Allen FRANZCO ${ }^{1,2}$
}
${ }^{1}$ The Royal Victorian Eye and Ear Hospital, 32 Gisborne Street, East Melbourne, VIC, Australia
${ }^{2}$ Centre for Eye Research Australia, University of Melbourne, Level 7, 32 Gisborne Street, East Melbourne, VIC, Australia

Correspondence: Dr Penelope J Allen, The Royal Victorian Eye and Ear Hospital, 32 Gisborne Street, East Melbourne, Melbourne, Vic. 3002, Australia. Email: pjallen@melbourneretina.com.au

Received 26 November 2017; accepted 5 December 2017

Conflict of interest: None

Funding sources: None

This is the author manuscript accepted for publication and has undergone full peer review but has not been through the copyediting, typesetting, pagination and proofreading process, which may lead to differences between this version and the Version of Record. Please cite this article as doi: $10.1111 /$ ceo.13130

This article is protected by copyright. All rights reserved. 
We thank Grzybowski and Turczynowska (1) for their interest in our recent publication (2). The Endophthalmitis Vitrectomy Study (EVS) (3) is now over two decades old, and the criterion of early vitrectomy within six hours was strictly adhered to as part of this prospective, limited-time study. Our retrospective study exposes the limitations of such a strict criterion, even in the setting of a quaternary specialist eye hospital. The practicalities of access to care, logistics and fasting status often delay surgery beyond a six-hour window, and it was never our intention to perform a direct comparison. Instead, we present a practical, "realworld" perspective of early vitrectomy, which may be more useful in everyday settings.

While advances in vitrectomy technology and techniques, including those mentioned by Kuhn and Gini (4) have improved the safety profile of vitrectomy in endophthalmitis, it is still overwhelmingly the most difficult and risky procedures to perform, compared to other indications for vitrectomy. (5) It is for this very reason that Kuhn and Gini draw attention to the EVS protocol of limited vitreous removal, which possibly reduced the rate of retinal detachment in vitrectomised eyes compared to the nonsurgical group. The decision to perform vitrectomy in endophthalmitis is still difficult and continues to be debated. To justify an intervention that is highly risky for iatrogenic damage in our own hands, we often require a higher threshold of evidence for benefit against non-intervention. Such procedures should not be taken lightly and should be performed by expert hands.

Clinical assessment is vital in making treatment decisions in endophthalmitis. Microbiological information, when available, is a useful adjunct to decision-making. We acknowledge that whilst this is institution-dependent, there are many similar institutions, for whom gram stain results are readily available within 1-2 hours. We routinely use this information, as it is well within the time needed to admit a 
patient, obtain vitreoretinal opinion, and prepare them for possible surgery. Therefore, we find that early microbiological results do not delay treatment decisions, but instead add to the clinical assessment of patients presenting with a potentially aggressive infection which is likely to lead to severe visual loss, blindness or loss of an eye.

\section{REFERENCES}

1. Grzybowski A, Turcynowska M. Predictors of visual outcome and the role of early vitrectomy in Streptococcal endophthalmitis: comment. Clin Exp Ophthalmo/2017 2. Kurniawan ED, Rocke JR, Sukphal SS, Allen PJA. Predictors of visual outcome and the role of early vitrectomy in Streptococcal endophthalmitis. Clin Exp Ophthalmo/ 2017

3. Endophthalmitis Vitrectomy Study Group. Results of the Endophthalmitis Vitrectomy Study - A Randomized Trial of Immediate Vitrectomy and of Intravenous Antibiotics for the Treatment of Postoperative Bacterial Endophthalmitis. Arch Ophthalmol 1995;113 12: 1479-96.

4. Kuhn F, Gini G. Ten years after... are findings of the Endophthalmitis Vitrectomy Study still relevant today? Graefes Arch Clin Exp Ophthalmo/ 2005;243 12: 1197-9. 5. Meredith TA. Chapter 133: Vitrectomy for Infectious Endophthalmitis. Retina 4th edition. St Louis: Elsevier; 2006. 


\section{University Library}

\section{- M I N E R VA \\ A gateway to Melbourne's research publications}

Minerva Access is the Institutional Repository of The University of Melbourne

Author/s:

Kurniawan, ED;Rocke, JR;Sandhu, SS;Allen, PJ

Title:

Predictors of visual outcome and the role of early vitrectomy in streptococcal endophthalmitis: response

Date:

2018-07-01

\section{Citation:}

Kurniawan, E. D., Rocke, J. R., Sandhu, S. S. \& Allen, P. J. (2018). Predictors of visual outcome and the role of early vitrectomy in streptococcal endophthalmitis: response. CLINICAL AND EXPERIMENTAL OPHTHALMOLOGY, 46 (5), pp.578-578. https:// doi.org/10.1111/ceo.13130.

Persistent Link:

http://hdl.handle.net/11343/283513 